\title{
TNF $\alpha$ Induces Choroid Plexus Epithelial Cell Barrier Alterations by Apoptotic and Nonapoptotic Mechanisms
}

\author{
Christian Schwerk, ${ }^{1}$ Kasia Rybarczyk, ${ }^{2}$ Frank Essmann, ${ }^{3}$ Annette Seibt, ${ }^{2}$ \\ Marie-Louise Mölleken, ${ }^{2}$ Patrick Zeni, ${ }^{4}$ Horst Schroten, ${ }^{1}$ and Tobias Tenenbaum ${ }^{1}$ \\ ${ }^{1}$ Pediatric Infectious Diseases, Department of Pediatrics, Medical Faculty Mannheim, Heidelberg University, \\ Theodor-Kutzer-Ufer 1-3, 68167 Mannheim, Germany \\ ${ }^{2}$ Department of General Pediatrics, University Children's Hospital, Heinrich Heine University, Moorenstr. 5, \\ 40225 Düsseldorf, Germany \\ ${ }^{3}$ Interfaculty Institute for Biochemistry, University of Tübingen, Hoppe-Seyler-Str. 4, 72076 Tübingen, Germany \\ ${ }^{4}$ Department of Biochemistry, Westfalian Wilhelms University, Wilhelm-Klemm-Str. 2, 48194 Münster, Germany
}

Correspondence should be addressed to Tobias Tenenbaum, tobias.tenenbaum@umm.de

Received 10 July 2009; Revised 16 November 2009; Accepted 14 January 2010

Academic Editor: Amanda McCann

Copyright (C) 2010 Christian Schwerk et al. This is an open access article distributed under the Creative Commons Attribution License, which permits unrestricted use, distribution, and reproduction in any medium, provided the original work is properly cited.

\begin{abstract}
The choroid plexus epithelium constitutes the structural basis of the blood-cerebrospinal fluid barrier. Since the cytokine TNF $\alpha$ is markedly increased during inflammatory diseases in the blood and the central nervous system, we investigated by which mechanisms TNF $\alpha$ induces barrier alteration in porcine choroid plexus epithelial cells. We found a dose-dependent decrease of transepithelial electrical resistance, increase of paracellular inulin-flux, and induction of histone-associated DNA fragmentation and caspase- 3 activation after TNF $\alpha$ stimulation. This response was strongly aggravated by the addition of cycloheximide and could partially be inhibited by the NF- $\kappa$ B inhibitor CAPE, but most effectively by the pan-caspase-inhibitor zVAD-fmk and not by the JNK inhibitor SP600125. Partial loss of cell viability could also be attenuated by CAPE. Immunostaining showed cell condensation and nuclear binding of high-mobility group box 1 protein as a sign of apoptosis after TNF $\alpha$ stimulation. Taken together our findings indicate that TNF $\alpha$ compromises PCPEC barrier function by caspase and NF- $\kappa$ B dependent mechanisms.
\end{abstract}

\section{Introduction}

In the mammalian brain the cerebrospinal fluid (CSF) is produced by the choroid plexus (CP), which not only regulates homeostasis in the central nervous system (CNS), but also participates in neurohumoral brain modulation as well as neuroimmune interaction $[1,2]$. The $\mathrm{CP}$ is a highly perfused organ; the endothelial and epithelial cells of the CP separate the blood from the CSF. Whereas the endothelial cells are fenestrated, the epithelial cells of the $\mathrm{CP}$ are closely connected to each other by tight junctions (TJs) and constitute the structural basis of the blood-CSF barrier. The barrier function of the TJs can be subject to modulation and thereby regulates the entry of physiologically important substances as well as immune modulatory components and cells during inflammatory events $[3,4]$.
Over the course of neuroinflammatory diseases, including meningitis after infection with bacterial pathogens, the composition of the CSF undergoes significant changes including the accumulation of certain cytokines $[5,6]$. In agreement, expression of the proinflammatory cytokine $\mathrm{TNF} \alpha$ is markedly increased in porcine choroid plexus epithelial cells after infection with the gram-positive bacterium Streptococcus suis [7]. Subsequently, injury of the $\mathrm{CP}$ due to inflammatory responses may cause further impairment of the blood-CSF barrier and allow enhanced entry of immune system cells into the CNS [1,2].

TNF $\alpha$ exhibits pleiotropic functions and is involved in several cellular processes including inflammation, immune responses, cell death and cell proliferation. TNF $\alpha$ mediates its function via the two TNF receptors (TNFRs). TNFR1 is expressed on all cells, whereas TNFR2 is found on endothelial 
cells and cells of the immune system [8-10]. Signalling through TNFR ligation can initiate (i) programmed cell death (apoptosis), (ii) antiapoptotic and proinflammatory responses through NF- $\kappa \mathrm{B}$, and (iii) activation of the mitogen activated protein kinase (MAPK) JNK signalling pathway [11]. These signal transduction mechanisms are tightly interconnected with each other through a complex network and their modulation allows to shifting the cellular state either towards survival or cell death $[11,12]$.

Employing an in vitro model of the blood-CSF barrier we have previously shown that cell death by apoptosis and necrosis participates in barrier loss of porcine choroid plexus epithelial cells (PCPEC) after infection with Streptococcus suis [13]. Furthermore, treatment of PCPEC with TNF $\alpha$ caused distinct inflammatory responses including tight junction and actin cytoskeleton disorganisation, the upregulation of cell adhesion molecules and an increased activity of matrix metalloproteases in PCPEC supernatants [14]. We now investigated in detail the involvement of apoptotic and nonapoptotic mechanisms in the modulation of PCPEC barrier function in response to treatment with TNF $\alpha$.

\section{Materials and Methods}

2.1. Preparation and Cultivation of Choroid Plexus Epithelial Cells. Epithelial cells from porcine choroid plexus were obtained by a modified preparation as basically described by Gath et al. [15]. Briefly, brains from freshly slaughtered pigs were dissected and the choroid plexus tissue from the lateral and the fourth ventricles was removed and treated with consecutive cold and warm trypsinisation $(0.2 \%$ solution, Biochrom, Berlin, Germany, 45 minutes at $4^{\circ} \mathrm{C}$, 20 minutes at $37^{\circ} \mathrm{C}$ ). The cells were centrifuged at 20 $\times \mathrm{g}$ for 10 minutes and resuspended in DMEM/HAM's F12 1: 1 supplemented with $4 \mathrm{mM} \mathrm{L}$-glutamine, $10 \%$ heat inactivated fetal calf serum, $5 \mu \mathrm{g} / \mathrm{mL}$ insuline, and penicillin $(100 \mathrm{U} / \mathrm{mL}) /$ streptomycin $(100 \mu \mathrm{g} / \mathrm{mL})$. In order to suppress the growth of contaminating fibroblast like cells, $20 \mu \mathrm{M}$ of cytosine-arabinoside were added. The cells were either plated on 6-, 24-, or 96-well plates (Falcon, BD, Le Pont De Claix, France) using a seeding density of $50 \mathrm{~cm}^{2} / \mathrm{g}$ wet weight of choroid plexus tissue or on laminin coated permeable Transwell filter membranes (Costar, Cambridge, USA) with a diameter of $12 \mathrm{~mm}$. Upon confluence, PCPEC had a seeding density of approximately $1 \times 10^{5} \mathrm{cells} / \mathrm{cm}^{2}$. After reaching confluence they were cultivated in serum-free medium and were used for the experiments 3-5 days later. All experiments were performed with cells that had been cultured in SFM for at least 3-4 days and exhibited high TEER values of at least $1000 \mathrm{Ohm} \times \mathrm{cm}^{2}$ on Transwell filter membranes.

2.2. Stimulation of Cells and Inhibition Studies. To investigate PCPEC barrier function recombinant porcine $\mathrm{TNF} \alpha$ (R\&D systems, Minneapolis, USA) was applied at 1, 10, or $100 \mathrm{ng} / \mathrm{mL}$ apically or basolaterally as indicated in the respective experiments. The protein synthesis inhibitor Cycloheximide was used at a concentration of $1 \mu \mathrm{g} / \mathrm{mL}$, the NF- $\kappa$ B inhibitor caffeic acid phenethyl ester (CAPE) at $5 \mu \mathrm{M}$, the JNK-inhibitor SP600125 at $10 \mu \mathrm{M}$ (all products were purchased from Merck, Darmstadt, Germany), and the pan-caspase-inhibitor $N$-benzyloxycarbonyl-ValAla-Asp-fluoromethyl-ketone (zVAD-fmk; ICN, Heidelberg, Germany) was used at $10 \mu \mathrm{M}$. PCPECs were preincubated with inhibitors for 2 hours prior to the experiment. Staurosporine (Calbiochem, Germany) was added at a concentration of $1 \mu \mathrm{M}$.

2.3. Measurement of Transepithelial Electrical Resistance (TEER). Confluence of the PCPEC monolayers and barrier properties were documented by measuring TEER using an epithelial tissue voltohmmeter (EVOM, World Precision Instruments, Sarasota, FL, USA) and the STX-2 electrode system. PCPEC inverted cultures were used when TEER values reached more than $1000 \Omega \times \mathrm{cm}^{2}$. In TNF $\alpha$ assays TEER was monitored over a range of 48 hours. Resistance values of cells in medium alone were used as negative control values and stayed above $1000 \Omega \times \mathrm{cm}^{2}$ during all experiments.

2.4. Determination of Paracellular Permeability. TEER changes reflect variation in tight junction integrity, although they may also indicate changes in permeability at the membrane level. As an independent measure of paracellular permeability of choroid plexus epithelium monolayers, we examined the passage of a membrane-impermeable water-soluble compound FITC-inulin (Sigma, Deisenhofen, Germany) across cell monolayers. The FITC-inulin flux was determined by measuring its paracellular passage from the apical to the basolateral compartment of the Transwell filter. FITC-inulin was dissolved in culture medium. The tracer solution $(100 \mu \mathrm{g} / \mathrm{mL})$ was loaded into the apical Transwell filter compartment during the incubation period. After stimulation with $\mathrm{TNF} \alpha$ medium samples were collected from the basolateral Transwell compartment over a range of poststimulation intervals of 24 hours and the fluorescence was determined by measurement in a Tecan Infinite M200 Multiwell reader (Tecan, Switzerland).

2.5. DNA Fragmentation Assay. For identification of apoptotic cells an ELISA was used measuring intracellular histone-associated DNA fragments according to the manufacturer's protocol (Cell Death Detection ELISA PLUS; Roche Molecular Biochemicals, Mannheim, Germany). This quantitative sandwich enzyme immunoassay specifically detects the histone region of mono- and oligonucleosomes that are released during apoptosis. PCPECs were stimulated with TNF $\alpha$ for 8 hours, 24 hours, and 48 hours with or without the indicated inhibitors. After stimulation the cells were lysed and the supernatant containing the nuclear derived histone-associated DNA fragments was used for ELISA. Absorption was monitored by reading the plate at $405 \mathrm{~nm}$ using a Flow Titertek Multiscan PLUS (ICN, Heidelberg, Germany). Apoptosis was measured in duplicate from each group and expressed as the absorbance (optical density) of the experimental cell lysates after 30 minutes of development. 
Apical stimulation

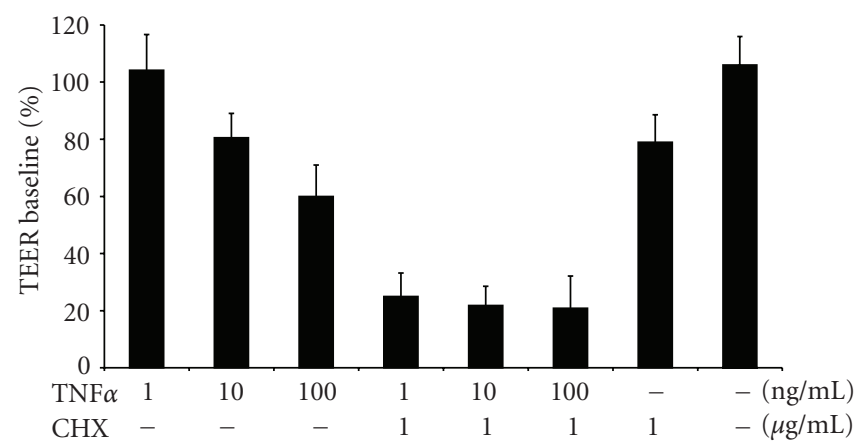

(a)
Basolateral stimulation

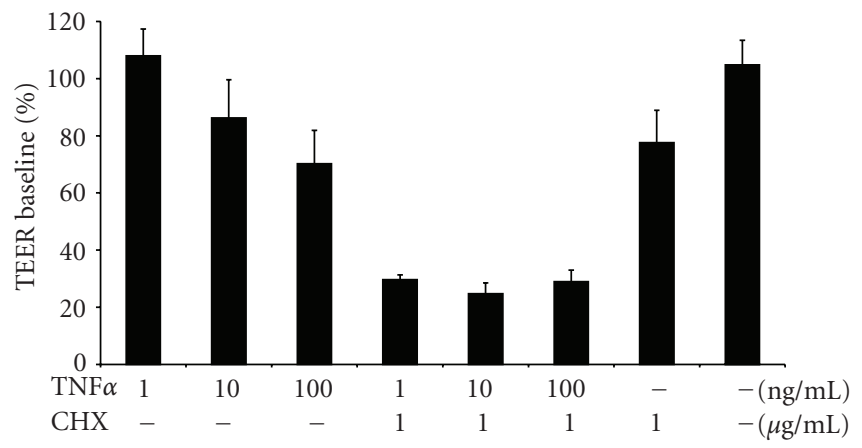

(b)

FIGURE 1: Apical and basolateral TNF $\alpha$ stimulations induce an equal effect on PCPEC barrier function. PCPECs grown on Transwell filters were stimulated apically (a) or basolaterally (b) with different doses of TNF $\alpha(1,10,100 \mathrm{ng} / \mathrm{mL})$ with or without the protein synthesis inhibitor cycloheximide $(1 \mu \mathrm{g} / \mathrm{mL})$. Effects on barrier function by measuring Transepithelial electrical resistance (TEER) were determined at 24 hours. The TEER results are expressed as a percentage of baseline. The data shown are mean \pm SEM of four independent experiments, each performed in duplicate.

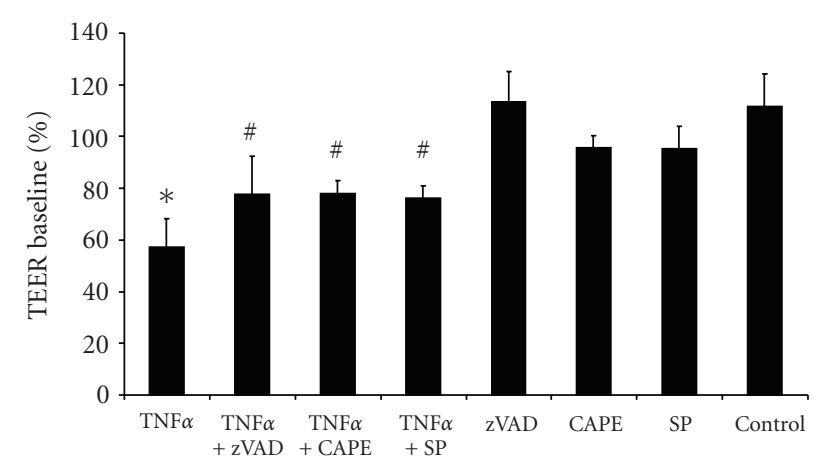

(a)

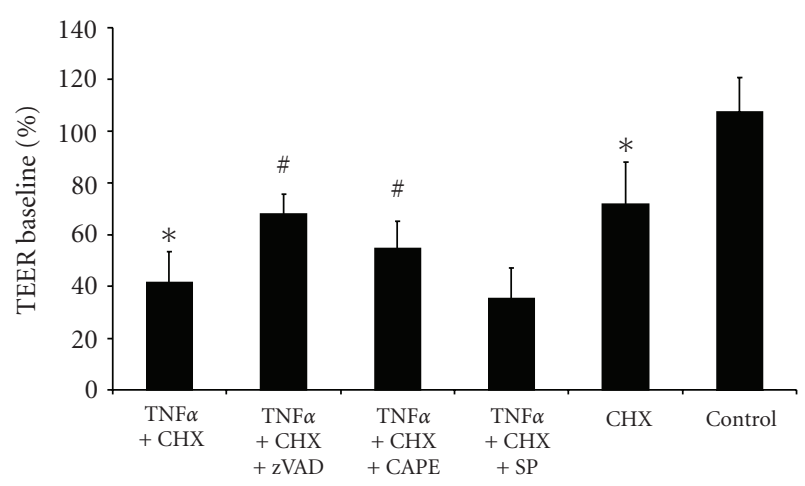

(b)

FIgURE 2: TNF $\alpha$-induced decrease of TEER in PCPEC is caspase- and NF- $\kappa$ B-dependent. Effects of the pan-caspase inhibitor zVAD-fmk $(10 \mu \mathrm{M})$, the NF- $\kappa \mathrm{B}$ inhibitor CAPE $(5 \mu \mathrm{M})$, and the JNK-inhibitor SP600125 $(10 \mu \mathrm{M})$ on TNF $\alpha$-induced decrease of TEER in PCPEC were determined at 24 hours. PCPECs were stimulated apically with TNF $\alpha(100 \mathrm{ng} / \mathrm{mL})$ with (b) or without (a) cycloheximide ( $1 \mu \mathrm{g} / \mathrm{mL})$. The TEER results are expressed as a percentage of baseline. The data shown are mean \pm SEM of four independent experiments, each performed in duplicate. ${ }^{\# P}$-value of $<.05$ compared to TNF $\alpha$ stimulated PCPEC without inhibitor; ${ }^{*} P$-value of $<.05$ compared to unstimulated PCPEC.

2.6. Assessment of Caspase Activity. Caspase activity was measured using a fluorometric assay as described in [16]. In brief, of TNF $\alpha$ stimulated cells PCPECs were first lysed in $75 \mu \mathrm{L}$ lysis buffer to collect their intracellular contents. For the fluorometric cleavage assay, $50 \mu \mathrm{g}$ of the cell extracts were directly dissolved in $200 \mu \mathrm{L}$ substrate buffer $(50 \mathrm{mM}$ HEPES pH 7.3, $100 \mathrm{mM} \mathrm{NaCl}, 10 \%$ sucrose, 0.1\% CHAPS, $10 \mathrm{mM}$ DTT) supplemented with $50 \mu \mathrm{M}$ of the fluorogenic substrates Ac-DEVD-AMC for caspase-3, Ac-IETD-AMC for caspase-8, or Ac-LEHD-AMC for caspase-9 (MP Biomedicals, Eschwege, Germany). The release of aminomethylcoumarin was measured fluorometrically over 5 hours at $37^{\circ} \mathrm{C}$ using a Lambda Fluro 320 Plus fluorometer (Biotek, Bad Friedrichsall, Germany; excitation: $360 \mathrm{~nm}$, emission: $475 \mathrm{~nm}$ ). The catalytic activities are expressed as fluorogenic units $(\mathrm{FU}) / \mathrm{min}$.
2.7. Measurement of Cell Viability. Vitality of the cells was measured using Life/Dead assay (Molecular Probes, Göttingen, Germany). The viability kit contains two components. Calcein penetrates the membrane of vital cells, and esterases in the cytoplasm render it fluorescent (green). Ethidium homodimer is not able to penetrate intact cell membranes but adheres to nucleic acids of damaged cells (red fluorescent cells). For cell staining a $2 \mu \mathrm{M}$ solution ethidium homodimer and a $4 \mu \mathrm{M}$ solution of calcein-AM were used. The results were photodocumented by fluorescence microscopy.

\subsection{Measurement of Lactate Dehydrogenase (LDH) Activity.} Cell integrity was determined after treatment by measuring the lactate dehydrogenase activity in the culture supernatant using a commercially available kit (Roche, Mannheim, 


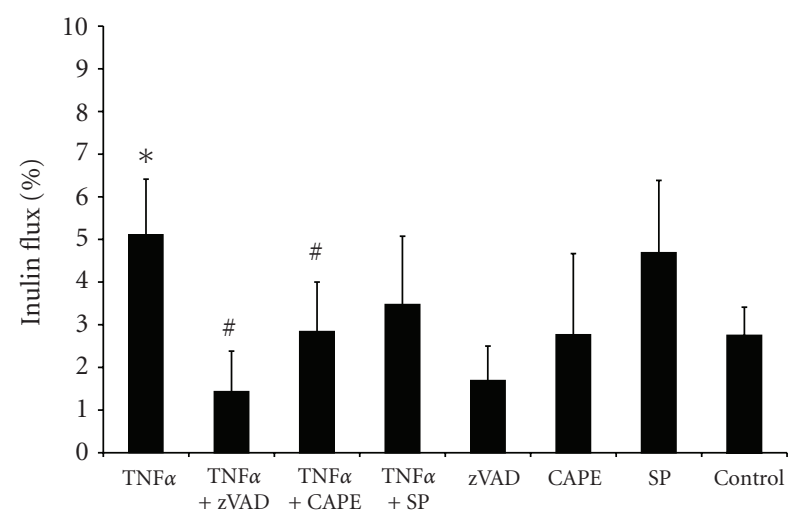

(a)

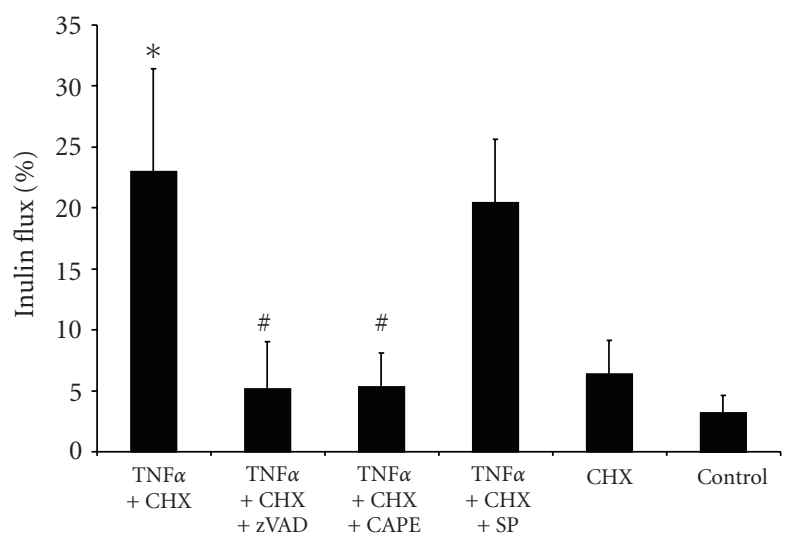

(b)

FIGURE 3: TNF $\alpha$-induced increase of paracellular inulin flux in PCPEC is caspase- and NF- $\kappa \mathrm{B}$-dependent. Effects of the pan-caspase inhibitor zVAD $(10 \mu \mathrm{M})$, the NF- $\kappa$ B inhibitor CAPE $(5 \mu \mathrm{M})$, and the JNK-inhibitor SP600125 $(10 \mu \mathrm{M})$ on TNF $\alpha$-induced increase of paracellular FITC-inulin flux in PCPECs were determined at 24 hours. The FITC-inulin flux was measured in the apical-to-basolateral direction with or without stimulation and is expressed as percentage of tracer in the basolateral compartment. PCPEC were stimulated apically with $\mathrm{TNF} \alpha(100 \mathrm{ng} / \mathrm{mL})$ with (b) or without (a) cycloheximide $(1 \mu \mathrm{g} / \mathrm{mL})$. The data shown are mean \pm SEM of four independent experiments, each performed in duplicate. ${ }^{*} P$-value of $<.05$ compared to TNF $\alpha$ stimulated PCPEC without inhibitor; ${ }^{*} P$-value of $<.05$ compared to unstimulated PCPEC.

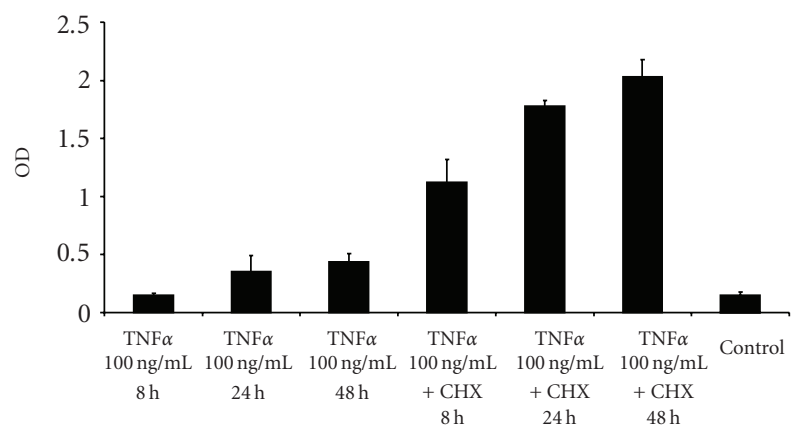

(a)

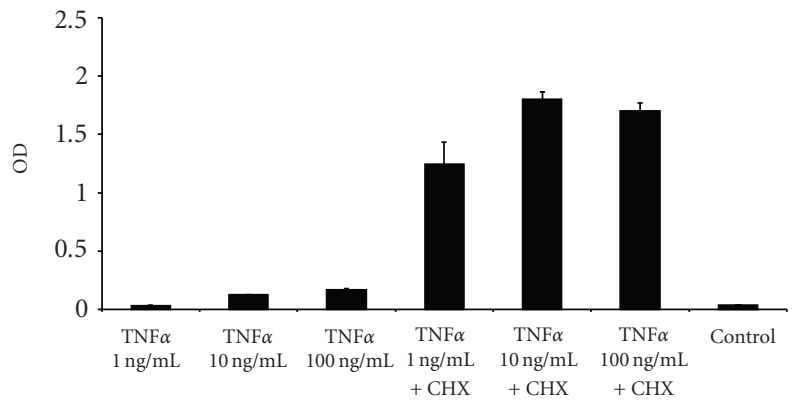

(b)

FIgURE 4: TNF $\alpha$ induces DNA-fragmentation in PCPEC. TNF $\alpha$-induced apoptosis was determined by ELISA measuring the number of cellular histone-associated DNA fragments. (a) The concentration of histone-associated DNA-fragments was determined 8 hours, 24 hours, and 48 hours following apical stimulation with TNF $\alpha$. PCPEC were stimulated apically with TNF $\alpha(100 \mathrm{ng} / \mathrm{mL})$ alone or costimulated with cycloheximide $(1 \mu \mathrm{g} / \mathrm{mL})$. The data shown are mean \pm SEM of three independent experiments, each performed in duplicate. (b) Appearance of histone-associated DNA fragments after 24 hours treatment with different doses of TNF $\alpha(1,10,100 \mathrm{ng} / \mathrm{mL})$ in presence or absence of cycloheximide $(1 \mu \mathrm{g} / \mathrm{mL})$. A representative experiment out of three performed in duplicates is shown. OD, optical density.

Germany). LDH release into the medium was expressed as the percentage of total $\mathrm{LDH}$ (i.e., $\mathrm{LDH}$ present in medium and the cells).

2.9. Immuncytochemistry. Cells were plated and observed in 6 wells. After stimulation with TNF $\alpha$ cells were washed with HBSS/HEPES, fixed with $\mathrm{PBS} / 4 \%$ paraformaldehyde, and permeabilized with $\mathrm{PBS} / 0.5 \%$ Triton X-100. HMGB1 was detected by indirect immunofluorescence using an antiHMGB1 antibody (BD Biosiences, Heidelberg, Germany) at 1 : 500 dilution for 12 hours at $4^{\circ} \mathrm{C}$ and chicken anti-rabbit antibody coupled to Alexa fluor 594 (Molecular Probes, Oregon, USA) at $1: 250$ dilution for 15 minutes at $4^{\circ} \mathrm{C}$. Cells were also stained with $4^{\prime}$-6-diamidino-2-phenylindole dihydrochloride (DAPI, $100 \mathrm{ng} / \mathrm{mL}$ ) dilution for 5 minutes at room temperature and observed on an Axioplan 2 microscope with filter set 2 and 31 (Carl Zeiss, Göttingen, Germany).

2.10. Data Analysis. Data are presented as means \pm SEM. The statistical significance between the groups comparisons was determined by Student's $t$-test. A probability value of less than.05 was considered statistically significant.

\section{Results}

To investigate the influence of TNF $\alpha$ on PCPEC barrier function we treated PCPEC monolayers grown on Transwell filters with TNF $\alpha$ for 24 hours and measured the transepithelial electrical resistance (TEER). Addition of increasing 


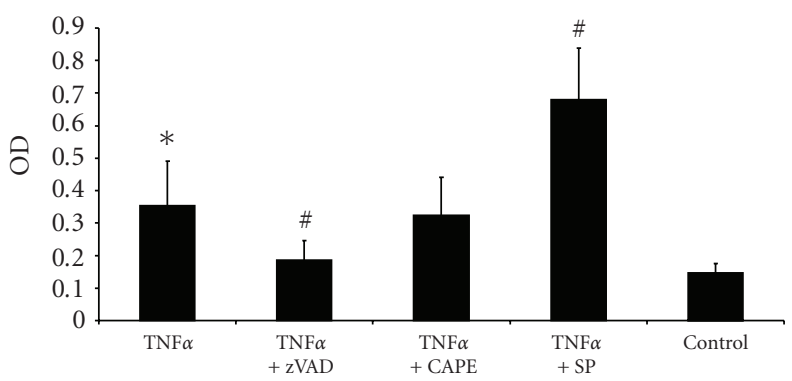

(a)

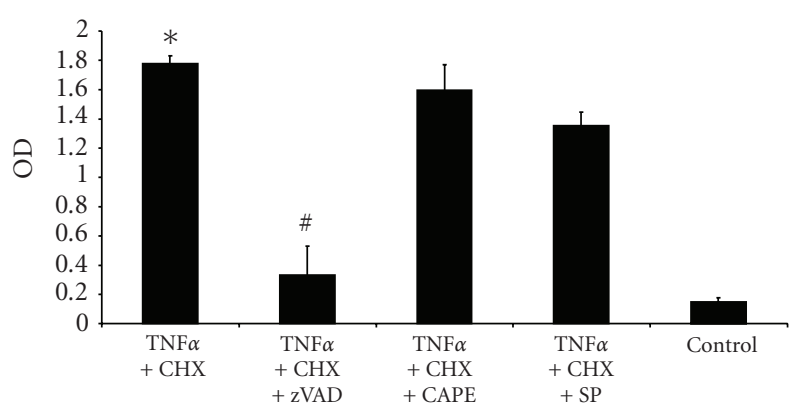

(b)

Figure 5: Caspase inhibition prevents TNF $\alpha$-induced DNA fragmentation. Influences of inhibitors of caspases, NF- $\kappa \mathrm{B}$, and JNK were analyzed in respect to TNF $\alpha$-induced PCPEC DNA fragmentation. PCPECs were stimulated apically with TNF $\alpha$ ( $100 \mathrm{ng} / \mathrm{mL}$ ) with (b) or without (a) cycloheximide $(1 \mu \mathrm{g} / \mathrm{mL})$. Cells were additionally preincubated with zVAD $(10 \mu \mathrm{M})$, CAPE $(5 \mu \mathrm{M})$ or SP600125 (10 $\mu \mathrm{M})$ for 2 hours as indicated. Results of these experiments were measured as an optical density (OD). The data shown are mean \pm SEM of three independent experiments, each performed in duplicate; ${ }^{\#} P$-value of <. 05 compared to treated PCPEC without inhibitor.

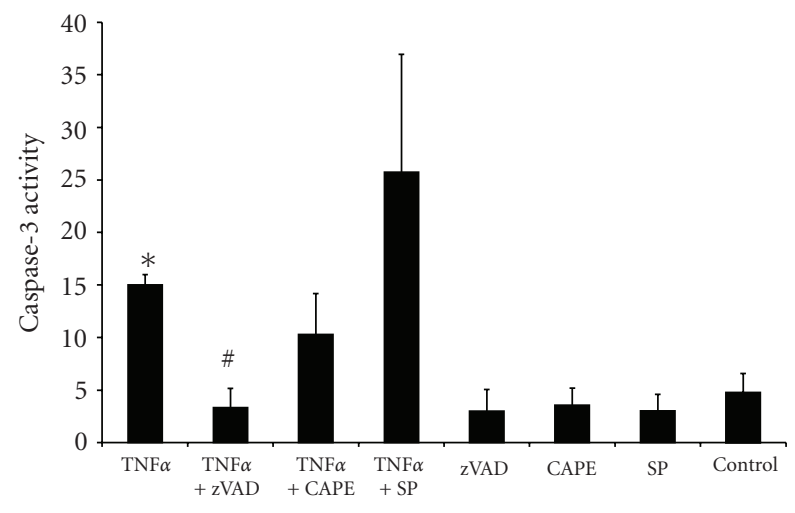

(a)

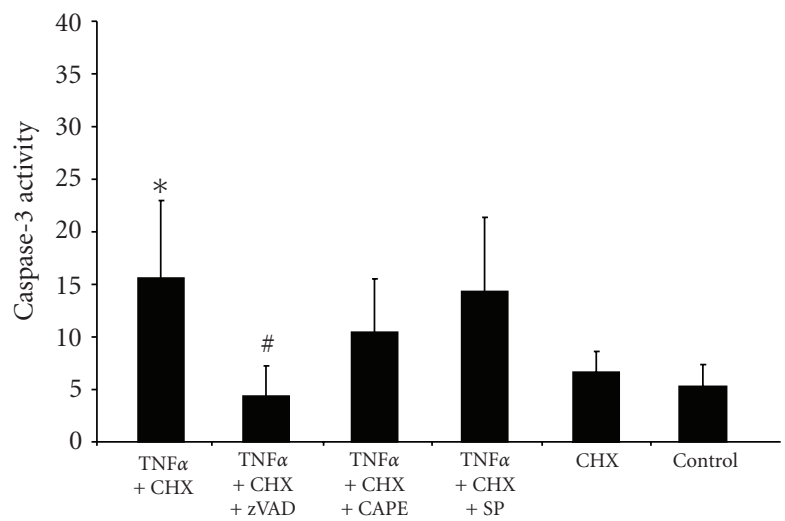

(b)

FIGURE 6: TNF $\alpha$ strongly activates caspase-3 in PCPEC. Caspase-3 activation (given as change of fluorescence per minute in arbitrary units $(\triangle \mathrm{FU} / \mathrm{min})$.$) was measured in PCPEC after stimulation with TNF \alpha(100 \mathrm{ng} / \mathrm{mL})$ for 24 hours with and without $\mathrm{zVAD}(10 \mu \mathrm{M}), \mathrm{CAPE}(5 \mu \mathrm{M})$ or SP600125 $(10 \mu \mathrm{M})$ preincubation for 2 hours (a), and coincubation with cycloheximide (CHX) $(1 \mu \mathrm{g} / \mathrm{mL})(\mathrm{b})$ and unstimulated control. The data shown are mean \pm SEM of three independent experiments $(n=3)$, each performed in duplicates. ${ }^{*} P$-value of $<$. 05 compared to unstimulated PCPEC; ${ }^{*}$-value of $<.05$ compared to TNF $\alpha \pm$ CHX stimulated PCPEC without inhibitor.

amounts of TNF $\alpha$ to the apical (Figure 1(a)) or basolateral (Figure 1(b)) side of PCPEC caused a dose-dependent drop of the TEER under both conditions at $10 \mathrm{ng} / \mathrm{mL}$ and $100 \mathrm{ng} / \mathrm{mL}$ of TNF $\alpha$, but not at $1 \mathrm{ng} / \mathrm{mL}$. Supression of protein synthesis by cotreatment with the translation elongation inhibitor cycloheximide (CHX) leads to a strong decrease of the TEER under all conditions investigated. Treatment with CHX alone also leads to a significant decrease of the TEER (Figures 1(a) and 1(b)). Since apical and basolateral TNF $\alpha$ application with or without CHX caused similar effects on PCPEC barrier function further experiments were only performed after apical stimulation of PCPEC.

$\mathrm{TNF} \alpha$ signaling is mediated by TNFRs and involves induction of apoptosis as well as activation of NF- $\kappa \mathrm{B}$ and JNK signaling pathways [9-11]. To dissect the contribution of the three above-mentioned pathways to modulation of PCPEC barrier function by apically added TNF $\alpha$, we preincubated PCPEC grown on Transwell filters with specific inhibitors prior to treatment with $\mathrm{TNF} \alpha$ in absence or presence of CHX. To inhibit apoptosis, the cells were preincubated for 2 hours with $10 \mu \mathrm{M}$ of the pan-caspase inhibitor zVAD-fmk. For attenuation of either NF- $\kappa$ B or JNK signaling, a 2 hours preincubation step with a low $(5 \mu \mathrm{M})$ concentration of the NF- $\kappa \mathrm{B}$ inhibitor caffeic acid phenethyl ester (CAPE) or with $10 \mu \mathrm{M}$ of the JNK inhibitor SP600125, respectively, was conducted. As can be seen in Figure 2(a) pretreatment with all three inhibitors caused a slight but significant attenuation of the TEER drop caused by subsequent treatment with TNF $\alpha$ alone, whereas none of the inhibitors by itself caused a significant change in TEER. When cells where stimulated with a combination of TNF $\alpha$ and CHX, pretreatment with both zVAD-fmk and CAPE significantly inhibited the observed strong decrease in TEER, with zVAD-fmk being a more potent inhibitor then CAPE (Figure 2(b)). Under these conditions SP600125 exhibited no significant effect (Figure 2(b)). 
In addition to the TEER values the paracellular inulin flux levels can be regarded as a measure for the barrier function of epithelia. Determination of the inulin flux revealed that apical addition of TNF $\alpha$ alone to the PCPEC caused a slight but significant increase in permeability (Figure 3(a)). In contrast, coincubation of the PCPEC with $\mathrm{TNF} \alpha$ and CHX leads to a strong increase in inulin flux (Figure 3(b)). Under both conditions preincubation with zVADfmk and CAPE significantly attenuated the gain in inulinflux, although zVAD-fmk demonstrated a stronger effect when PCPEC were activated with TNF $\alpha$ alone. Pretreatment with the JNK inhibitor SP600125 did not reveal an effect on permeability under any of the conditions investigated (Figure 3).

TNF $\alpha$ signal transduction via TNFRs is known to induce death receptor mediated apoptotic pathways [11]. One of the hallmarks of apoptosis is the appearance of oligonucleosomal DNA fragmentation caused by the caspase-activated DNA nuclease, CAD $[17,18]$. To investigate the level of apoptotic cell death in PCPEC after apical treatment with TNF $\alpha$ in the presence or absence of CHX we measured the appearance of cytoplasmic histone-associated DNA fragments by ELISA. Addition of TNF $\alpha$ alone resulted in a slight but significant increase in the apoptosis after 24 hours and 48 hours. In contrast, coincubation of PCPEC with TNF $\alpha$ and CHX leads. to a strong induction of programmed cell death already after 8 hours, which further increased after 24 hours and 48 hours (Figure 4(a)). Treatment of PCPEC with different doses of $\mathrm{TNF} \alpha(1,10,100 \mathrm{ng} / \mathrm{mL})$ for 24 hours caused only low levels of cell death in absence of CHX. In contrast significant amounts of apoptosis were observed when PCPEC were preincubated with CHX (Figure 4(b)). Levels of apoptosis correlated to some extend with the loss of PCPEC barrier function after treatment with $\mathrm{TNF} \alpha$ in presence and absence of CHX.

Additionally to the induction of apoptosis, TNF $\alpha$ activates signalling by NF- $\kappa \mathrm{B}$ and JNK, which are both known to contribute to inhibition of apoptosis due to the activation of antiapoptotic gene expression [11]. Therefore, we next analyzed the effect of zVAD-fmk, CAPE, and SP600125 on the appearance of oligonucleosomal DNA fragmentation in PCPEC. Inhibition of caspases by zVAD-fmk attenuated DNA fragmentation of PCPEC treated apically with TNF $\alpha$ in the absence (Figure 5(a)) or presence (Figure 5(b)) of CHX. In contrast, CAPE and SP600125 had no inhibitory effect under all conditions analysed (Figure 5). SP600125 did even lead to a slight increase in DNA fragmentation when compared to TNF $\alpha$ alone (Figure 5(a)). The three inhibitors zVAD, CAPE and SP600125 alone had no effect on DNA fragmentation (data not shown). To evaluate apoptosis in PCPEC in more detail we measured activation of caspase3 by a fluorometric assay (Figure 6). Noteworthy, active caspase- 3 levels in cells treated with TNF $\alpha$ for 24 hours were similar in absence (Figure 6(a)) and presence (Figure 6(b)) of cotreatment with CHX. In agreement with the appearance of DNA fragmentation, of the three inhibitors only zVAD-fmk was able to reduce the level of caspase-3 activation. Again, preincubation with SP600125 might cause rather a slight increase in activation of caspase- 3 in cells treated with TNF $\alpha$ alone. zVAD-fmk, CAPE or SP600125 did not cause caspase3 activation in absence of TNF $\alpha$ treatment (Figure 6(a)).

Treatment of cells with cytotoxic stimuli can result in both apoptosis and necrosis. In vivo, apoptotic cells are removed in a regulated manner allowing a minimum of inflammatory responses. In contrast, necrosis is characterized by the release of intracellular components leading to a proinflammatory response in surrounding tissues $[19,20]$. To analyze the cytotoxic effects of TNF $\alpha$ on PCPEC in more detail, we measured the release of lactate dehydrogenase (LDH), which is more closely associated with necrosis than with apoptosis. TNF $\alpha$ alone caused a slight but significant LDH-release, which could only be attenuated by CAPE, but not by zVAD-fmk or SP600125 (Figure 7(a)). When PCPEC were treated with the combination of TNF $\alpha$ and CHX a stronger LDH-release was observed. This release was inhibited by both zVAD-fmk and CAPE (Figure 7(b)). Treatment of PCPEC with zVAD-fmk, CAPE or SP600125 (Figure $7(\mathrm{a})$ ) or with CHX (Figure 7(b)) alone had no cytotoxic effect.

The high mobility group 1 (HMGB1) protein is known to be associated with condensed chromatin or to be released from cells undergoing either apoptosis or necrosis, respectively, [21]. PCPEC treated with TNF $\alpha$ in presence or absence of CHX were stained with DAPI and analyzed by immunofluorescence with an antibody against HMGB1. Apoptotic cells resulting from the different treatments contained HMGB1, confirming programmed cell death caused by either TNF $\alpha$ or TNF $\alpha$ in combination with CHX. Treatment of PCPEC with staurosporine was performed as a positive control for apoptosis. Cotreatment of PCPEC with TNF $\alpha$ and CHX as well as addition of staurosporine produced also cells with their HMGB1 released indicative of post-apoptotic necrosis (Figure 8(b)). Increased amounts of dead cells after incubation with the combination of TNF $\alpha$ and CHX compared to treatment with TNF $\alpha$ alone were confirmed by a Live/Dead assay (Figure 8(a)).

\section{Discussion}

The participation of proinflammatory cytokines in the pathophysiology of inflammatory CNS disease as bacterial meningitis is well recognized. Such cytokines have been implicated in epithelial barrier dysfunction $[22,23]$ and in inducing epithelial cell apoptosis [24]. Our study was designed to provide a detailed insight into the mechanism(s) by which proinflammatory cytokines like TNF $\alpha$ compromise PCPEC barrier function, and whether or not these are causally linked to apoptosis. Significant amount of TNF $\alpha$ $(45 \mathrm{ng} / \mathrm{mL})$ has been observed in the CSF of rabbits with experimental meningitis caused by Haemophilus influenzae type b lipooligosaccharide [25]. Additionally, concentrations reaching up to $40 \mathrm{ng} / \mathrm{mL}$ (mean $\sim 15 \mathrm{ng} / \mathrm{mL}$ ) have been described in serum for a porcine model of meningococcal shock [26].

The epithelial cells of the choroid plexus constitute the structural basis of the blood-CSF barrier and have been shown to respond to inflammatory challenge by the 


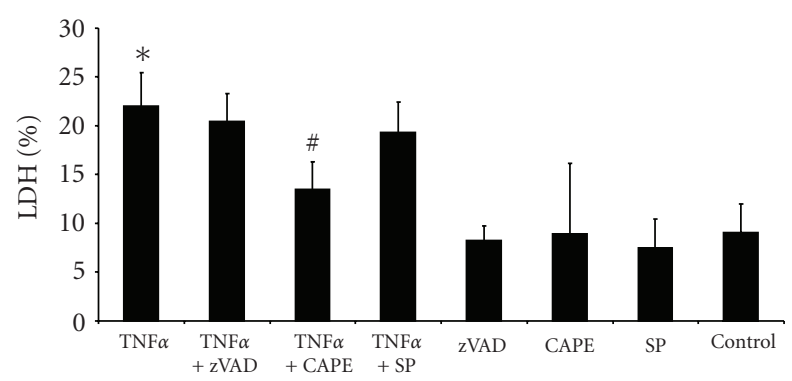

(a)

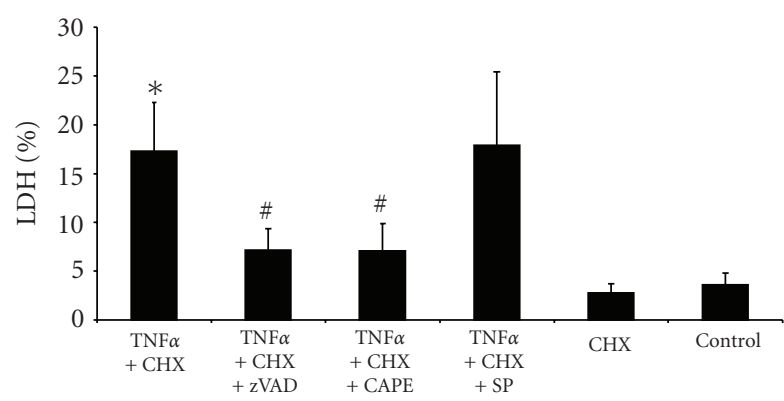

(b)

FIGURE 7: Inhibition of NF- $k$ B induction attenuates PCPEC cytotoxicity. Cytotoxicity in the presence of TNF $\alpha(100 \mathrm{ng} / \mathrm{mL}) \pm$ cycloheximide (CHX) $(1 \mu \mathrm{g} / \mathrm{mL})((\mathrm{a})$ and (b)) for 24 hours, was detected by measuring LDH activity in the supernatant. Cytotoxicity inhibition experiments in PCPEC cells were performed after preincubation with zVAD-fmk $(10 \mu \mathrm{M})$, CAPE $(5 \mu \mathrm{M})$ or SP600125 (10 $\mu \mathrm{M})$ for 2-hour. The data are expressed as the percentages of cytotoxicity in treated wells compared with cytotoxicity in control wells with PCPEC alone. The data shown are mean \pm SEM of three independent experiments, each performed in duplicate. ${ }^{*} P$-value of $<.05$ compared to unstimulated PCPEC; ${ }^{\#} P$-value of $<.05$ compared to TNF $\alpha \pm$ CHX stimulated PCPEC without inhibitor.

pleiotropic cytokine TNF $\alpha$ in an in vitro model employing primary porcine choroid plexus epithelial cells. During these studies TNF $\alpha$ was shown to alter tight junction function in part via matrix-metalloproteases [14]. Interestingly, the gene encoding for $\mathrm{TNF} \alpha$, among other inflammatory response genes, is upregulated in the same cellular system after infection with the gram-positive bacterium Streptococcus suis. Infection with $S$. suis affects the barrier function of the PCPEC in part by inducing cell death of PCPEC by apoptotic and necrotic mechanisms $[7,13]$.

$\mathrm{TNF} \alpha$ is known to exert its functions mainly via two TNFRs, TNFR1 and TNFR2 [8-10]. Although to our knowledge the distribution of TNFRs in the porcine brain has not been investigated, data from an in vivo rat model have indicated that in the choroid plexus TNFR1 is basally expressed and upregulated after challenge with lipopolysaccharide (LPS) or TNF $\alpha$, whereas low TNFR2 expression could only be detected after LPS or TNF $\alpha$ treatment [27]. We tested several antibodies against TNFR1 and TNFR2, but none of them recognized porcine TNFRs and therefore we could neither determine potential inhibitory effects (data not shown). TNF $\alpha$ induces distinct downstream regulatory pathways, notably TNFR-mediated apoptosis and induction of the NF- $\kappa \mathrm{B}$ and JNK signaling pathways [11].

In the present study we investigated the downstream effects contributing to choroid plexus epithelial cell barrier loss caused by TNF $\alpha$ in further detail. Treatment of PCPEC with TNF $\alpha$ for 24 hours caused low levels of apoptosis as evidenced by DNA fragmentation, chromatin condensation and activation of caspase-3, which could be overcome by the addition of zVAD-fmk. Under the same conditions a significant drop of the transepithelial membrane potential concomitant with an increase in paracellular permeability occurred indicating an impairment of barrier function. In HT-29/B6 epithelial cells leaks in epithelial barrier due to single-cell apoptosis, particularly following incubation with TNF $\alpha$, have been reported [24]. However, inhibition of TNF $\alpha$-induced pulmonary epithelial cell apoptosis only partially restored barrier function, which underscores the complexity of the mechanisms that regulate the biological response to this cytokine in inflammatory injury cascades. In our experiments, also a significant LDH release, which could be attenuated by the NF- $\kappa \mathrm{B}$ inhibitor CAPE but not zVADfmk, was observed pointing to additional necrotic events. However, even pretreatment with CAPE or ZVAD-fmk could not completely inhibit loss of PCPEC barrier function. These data support the hypothesis that not only cell death by apoptosis and necrosis, but also cell death independent effects contribute to blood-CSF barrier breakdown during inflammation in the CNS [13, 14, 28-31].

Hallmarks of apoptosis (DNA fragmentation, chromatin condensation) were strongly increased when protein synthesis was inhibited by CHX. This is most likely caused by the inhibition of NF- $\kappa \mathrm{B}$ mediated induction of survival and/or antiapoptotic proteins [32]. In parallel necrosis markers like LDH release and the detachment of HMGB1 from chromatin were strongly enhanced. These phenomena are most likely caused by post-apoptotic events or secondary necrosis occurring at late time points after the onset of apoptosis [33], which was initiated 24 hours prior to analysis of the cells. This is supported by the observation that caspase3 activity in cells treated with the combination of TNF $\alpha$ and CHX was similar to that of cells treated with TNF $\alpha$ only. It is likely that the cells had already passed maximum apoptosis and caspase- 3 activity at this time point and went into postapoptotic necrosis.

CAPE has been described to inhibit the activation of $\mathrm{NF}-\kappa \mathrm{B}$ and therefore it prevents the increased expression of antiapoptotic proteins, which explains antiinflammatory and proapoptotic effects of CAPE [34-36]. Noteworthy, in our analyses preincubation of TNF $\alpha$-induced cells with CAPE did not lead to increased apoptosis as might be expected. This is presumably due to the rather low concentrations $(5 \mu \mathrm{M})$ of CAPE applied, which might not have a strong enough impact on regulation of antiapoptotic gene expression mediated by NF- $\kappa$ B. Low concentrations of CAPE as used by others $[37,38]$ were employed since higher amounts displayed cytotoxicity in PCPEC (data not shown). Still, CAPE was 

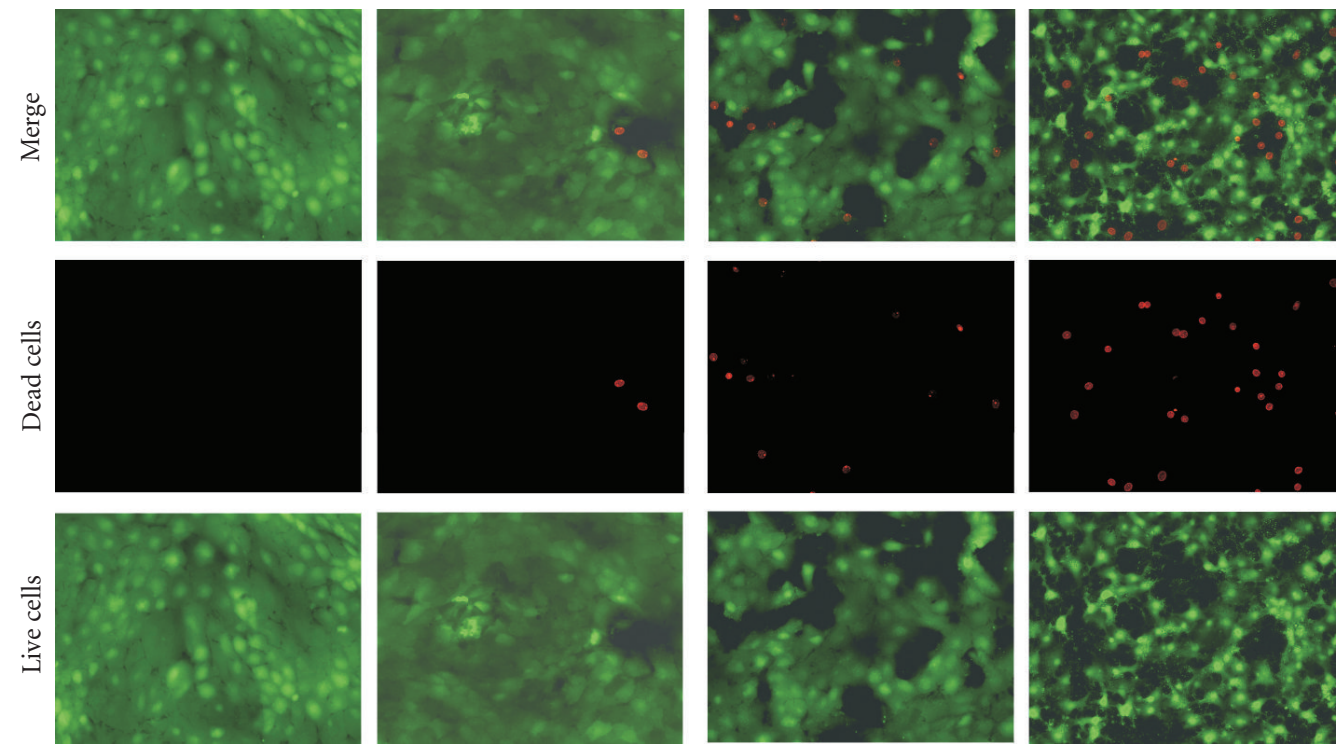

(a)
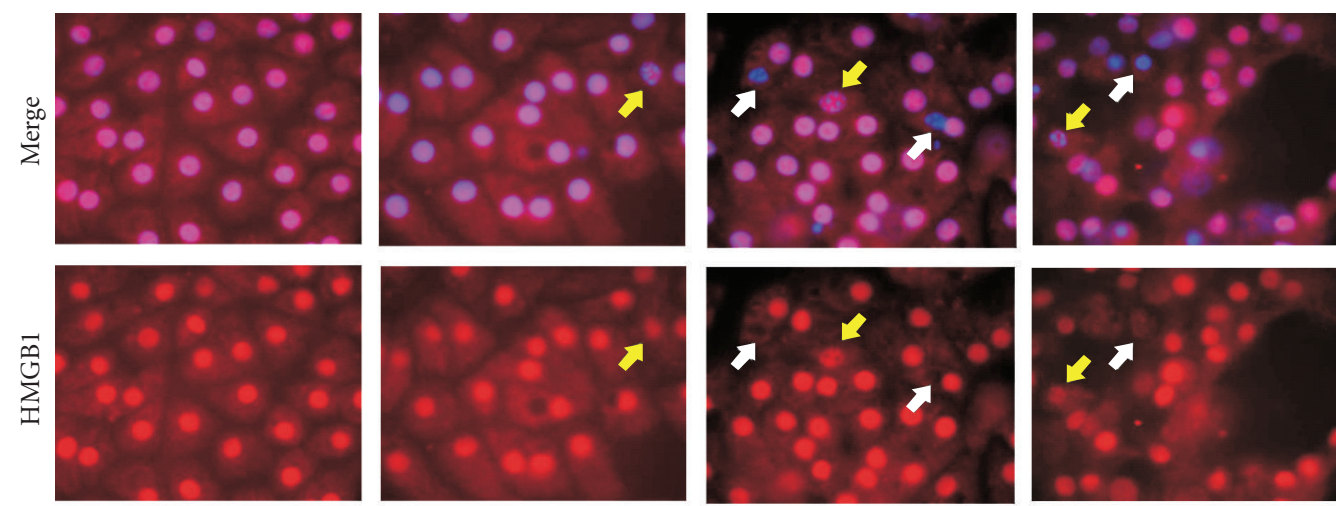

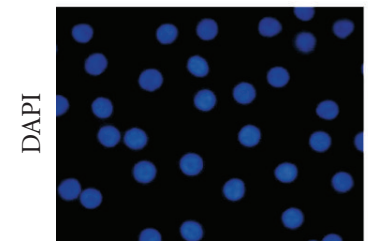

Control

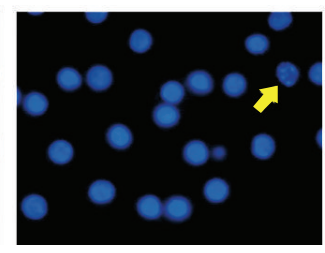

TNF $\alpha$

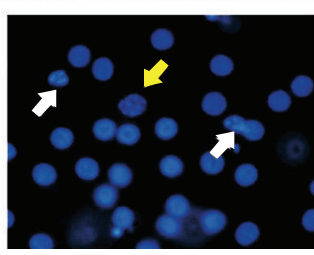

$\mathrm{TNF} \alpha+\mathrm{CHX}$

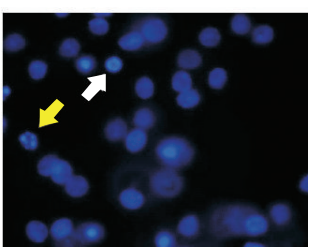

Staurosporine

(b)

Figure 8: TNF $\alpha$ induces HMGB1 release as well as HBGB1 binding in PCPEC. TNF $\alpha$-stimulated PCPEC loose membrane integrity. PCPEC were stimulated with TNF $\alpha(100 \mathrm{ng} / \mathrm{mL}) \pm$ cycloheximide $(\mathrm{CHX})(1 \mu \mathrm{g} / \mathrm{mL})$ for 10 hours. For a positive control PCPECs were treated with staurosporine $(1 \mu \mathrm{M})$. (a) Adherent cells were labelled according to the Live/Dead assay protocol. Vital cells are penetrated by calcein and show a green fluorescence, damaged cells were penetrated by ethidium homodimer and show red fluorescent nuclei. Images were obtained by fluorescence microscopy $(400 \times$ magnification) using a digital camera. (b) Chromatin of vital and apoptotic cells binds HMGB1 (red) whereas TNF $\alpha \pm \mathrm{CHX}$ and staurosporine stimulated PCPEC partly released HMGB1 from nuclei (i.e., post-apoptotic necrosis; white arrows). DAPI staining revealed also that TNF $\alpha \pm$ cycloheximide (CHX) resulted in chromatin condensation in PCPEC and binding of HMGB1 (i.e., apoptosis; yellow arrows). Both were detected by fluorescence microscopy $(1000 \times$ magnification $)$ and photographs were taken using a digital camera. The whole well was examined for each experimental condition in two separate experiments; results from one representative experiment are shown.

added in active concentrations, because preincubation with CAPE attenuated loss of barrier function caused by TNF $\alpha$ or the combination of TNF $\alpha$ with $\mathrm{CHX}$. TNF $\alpha$ was shown to increase tight junction permeability via NF- $\kappa \mathrm{B}$ activation in brain microvascular endothelial cells and Caco2 intestinal epithelial cells $[37,39]$. In line with our experiments, in the study by Ma and coworkers TNF $\alpha$ alone did not lead to a substantial amount of apoptosis and cotreatment with 
NF- $\kappa$ B inhibitors prevented loss of barrier function [39]. CAPE has been shown to exhibit antioxidant, antiinflammatory and immunomodulatory characteristics and can alter the intracellular redox state [40]. Possibly, CAPE inhibits additional downstream effects of NF- $\kappa \mathrm{B}$, which are involved in barrier breakdown. NF- $\kappa \mathrm{B}$ independent properties of CAPE may also be responsible for the observed effects. Since CAPE did not inhibit the apoptotic hallmarks caused at low levels by TNF $\alpha$ and in higher amounts by TNF $\alpha$ in combination with CHX, these downstream effects apparently do not involve apoptotic phenomena.

The JNK-inhibitor SP600125 attenuated loss of TEER caused by TNF $\alpha$ alone. We speculate that this effect is due to the inhibition of late proapoptotic functions mediated by JNK after prolonged induction with TNF $\alpha[12,41,42]$. Otherwise, we observed no significant effects of the JNK inhibitor, indicating that JNK signalling plays a rather minor role in $\mathrm{TNF} \alpha$ mediated barrier breakdown.

In summary, our data point to a role of apoptotic and necrotic phenomena as well as cell death independent mechanisms during the loss of PCPEC barrier function after treatment with TNF $\alpha$, mediated via TNFR downstream pathways involving activation of caspases and signaling by $\mathrm{NF}-\kappa \mathrm{B}$.

\section{Acknowledgments}

This work was supported by a Grant from the Deutsche Forschungsgemeinschaft (DFG653/2-1). The authors wish to thank J. Borkowski as well as our technicians N. Schmidt and N. Quednau for expert assistance.

\section{References}

[1] N. Strazielle and J.-F. Ghersi-Egea, "Choroid plexus in the central nervous system: biology and physiopathology," Journal of Neuropathology and Experimental Neurology, vol. 59, no. 7, pp. 561-574, 2000.

[2] B. Engelhardt, K. Wolburg-Buchholz, and H. Wolburg, "Involvement of the choroid plexus in central nervous system inflammation," Microscopy Research and Technique, vol. 52, no. 1, pp. 112-129, 2001.

[3] M. S. Balda and K. Matter, "Tight junctions," Journal of Cell Science, vol. 111, no. 5, pp. 541-547, 1998.

[4] B. M. Denker and S. K. Nigam, "Molecular structure and assembly of the tight junction," American Journal of Physiology, vol. 274, no. 1, pp. F1-F9, 1998.

[5] L. D. Gray and D. P. Fedorko, "Laboratory diagnosis of bacterial meningitis," Clinical Microbiology Reviews, vol. 5, no. 2, pp. 130-145, 1992.

[6] S. L. Hauser, T. H. Doolittle, R. Lincoln, R. H. Brown, and C. A. Dinarello, "Cytokine accumulations in CSF of multiple sclerosis patients: frequent detection of interleukin-1 and tumor necrosis factor but not interleukin-6," Neurology, vol. 40, no. 11, pp. 1735-1739, 1990.

[7] T. Tenenbaum, D. Matalon, R. Adam, et al., "Dexamethasone prevents alteration of tight junction-associated proteins and barrier function in porcine choroid plexus epithelial cells after infection with Streptococcus suis in vitro," Brain Research, vol. 1229, pp. 1-17, 2008.
[8] B. B. Aggarwal, "Signalling pathways of the TNF superfamily: a double-edged sword," Nature Reviews Immunology, vol. 3, no. 9, pp. 745-756, 2003.

[9] T. Hehlgans and K. Pfeffer, "The intriguing biology of the tumour necrosis factor/tumour necrosis factor receptor superfamily: players, rules and the games," Immunology, vol. 115, no. 1, pp. 1-20, 2005.

[10] V. Baud and M. Karin, "Signal transduction by tumor necrosis factor and its relatives," Trends in Cell Biology, vol. 11, no. 9, pp. 372-377, 2001.

[11] B. B. Aggarwal, "Tumour necrosis factors receptor associated signalling molecules and their role in activation of apoptosis, JNK and NF- $\kappa \mathrm{B}$," Annals of the Rheumatic Diseases, vol. 59, supplement 1, pp. i6-i16, 2000.

[12] J. Liu and A. Lin, "Wiring the cell signaling circuitry by the NF$\kappa \mathrm{B}$ and JNK1 crosstalk and its applications in human diseases," Oncogene, vol. 26, no. 22, pp. 3267-3278, 2007.

[13] T. Tenenbaum, F. Essmann, R. Adam, et al., "Cell death, caspase activation, and HMGB1 release of porcine choroid plexus epithelial cells during Streptococcus suis infection in vitro," Brain Research, vol. 1100, no. 1, pp. 1-12, 2006.

[14] P. Zeni, E. Doepker, U. S. Topphoff, S. Huewel, T. Tenenbaum, and H.-J. Galla, "MMPs contribute to TNF- $\alpha$-induced alteration of the blood-cerebrospinal fluid barrier in vitro," American Journal of Physiology, vol. 293, no. 3, pp. C855-C864, 2007.

[15] U. Gath, A. Hakvoort, J. Wegener, S. Decker, and H.-J. Galla, "Porcine choroid plexus cells in culture: expression of polarized phenotype, maintenance of barrier properties and apical secretion of CSF-components," European Journal of Cell Biology, vol. 74, no. 1, pp. 68-78, 1997.

[16] F. Essmann, H. Bantel, G. Totzke, et al., "Staphylococcus aureus $\alpha$-toxin-induced cell death: predominant necrosis despite apoptotic caspase activation," Cell Death and Differentiation, vol. 10, no. 11, pp. 1260-1272, 2003.

[17] S. Nagata, H. Nagase, K. Kawane, N. Mukae, and H. Fukuyama, "Degradation of chromosomal DNA during apoptosis," Cell Death and Differentiation, vol. 10, no. 1, pp. 108116, 2003.

[18] W. C. Earnshaw, "Nuclear changes in apoptosis," Current Opinion in Cell Biology, vol. 7, no. 3, pp. 337-343, 1995.

[19] M. Leist and M. Jaattela, "Four deaths and a funeral: from caspases to alternative mechanisms," Nature Reviews Molecular Cell Biology, vol. 2, no. 8, pp. 589-598, 2001.

[20] K. L. Rock and H. Kono, "The inflammatory response to cell death," Annual Review of Pathology: Mechanisms of Disease, vol. 3, pp. 99-126, 2008.

[21] P. Scaffidi, T. Misteli, and M. E. Bianchi, "Release of chromatin protein HMGB1 by necrotic cells triggers inflammation," Nature, vol. 418, no. 6894, pp. 191-195, 2002.

[22] C. B. Coyne, M. K. Vanhook, T. M. Gambling, J. L. Carson, R. C. Boucher, and L. G. Johnson, "Regulation of airway tight junctions by proinflammatory cytokines," Molecular Biology of the Cell, vol. 13, no. 9, pp. 3218-3234, 2002.

[23] H. Schmitz, M. Fromm, C. J. Bentzel, et al., "Tumor necrosis factor-alpha $(\mathrm{TNF} \alpha)$ regulates the epithelial barrier in the human intestinal cell line HT-29/B6," Journal of Cell Science, vol. 112, no. 1, pp. 137-146, 1999.

[24] A. H. Gitter, K. Bendfeldt, J.-D. Schulzke, and M. Fromm, "Leaks in the epithelial barrier caused by spontaneous and TNF- $\alpha$-induced single-cell apoptosis," FASEB Journal, vol. 14, no. 12, pp. 1749-1753, 2000.

[25] M. M. Mustafa, O. Ramilo, K. D. Olsen, et al., "Tumor necrosis factor in mediating experimental Haemophilus influenzae 
type B meningitis," Journal of Clinical Investigation, vol. 84, no. 4, pp. 1253-1259, 1989.

[26] E. W. Nielsen, B. C. Hellerud, E. B. Thorgersen, et al., "A new dynamic porcine model of meningococcal shock," Shock, vol. 32, no. 3, pp. 302-309, 2009.

[27] S. Nadeau and S. Rivest, "Effects of circulating tumor necrosis factor on the neuronal activity and expression of the genes encoding the tumor necrosis factor receptors (p55 and p75) in the rat brain: a view from the blood-brain barrier," Neuroscience, vol. 93, no. 4, pp. 1449-1464, 1999.

[28] R. Feuer, I. Mena, R. R. Pagarigan, S. Harkins, D. E. Hassett, and J. L. Whitton, "Coxsackievirus B3 and the neonatal CNS: the roles of stem cells, developing neurons, and apoptosis in infection, viral dissemination, and disease," American Journal of Pathology, vol. 163, no. 4, pp. 1379-1393, 2003.

[29] T. Takano, S. Takikita, and M. Shimada, "Experimental mumps virus-induced hydrocephalus: viral neurotropism and neuronal maturity," NeuroReport, vol. 10, no. 11, pp. 22152221, 1999.

[30] M. F. Falangola and C. K. Petito, "Choroid plexus infection in cerebral toxoplasmosis in AIDS patients," Neurology, vol. 43, no. 10, pp. 2035-2040, 1993.

[31] A. L. Smith, "Pathogenesis of Haemophilus influenzae meningitis," The Pediatric Infectious Disease Journal, vol. 6, no. 8, pp. 783-786, 1987.

[32] M. Karin and A. Lin, "NF- $\kappa$ B at the crossroads of life and death," Nature Immunology, vol. 3, no. 3, pp. 221-227, 2002.

[33] M. T. Silva, A. do Vale, and N. M. N. dos Santos, "Secondary necrosis in multicellular animals: an outcome of apoptosis with pathogenic implications," Apoptosis, vol. 13, no. 4, pp. 463-482, 2008.

[34] K. Natarajan, S. Singh, T. R. Burke Jr., D. Grunberger, and B. B. Aggarwal, "Caffeic acid phenethyl ester is a potent and specific inhibitor of activation of nuclear transcription factor NF- $\kappa \mathrm{B}$," Proceedings of the National Academy of Sciences of the United States of America, vol. 93, no. 17, pp. 9090-9095, 1996.

[35] P. Onori, S. DeMorrow, E. Gaudio, et al., "Caffeic acid phenethyl ester decreases cholangiocarcinoma growth by inhibition of NF- $\kappa \mathrm{B}$ and induction of apoptosis," International Journal of Cancer, vol. 125, no. 3, pp. 565-576, 2009.

[36] U.-H. Jin, K.-H. Song, M. Motomura, et al., "Caffeic acid phenethyl ester induces mitochondria-mediated apoptosis in human myeloid leukemia U937 cells," Molecular and Cellular Biochemistry, vol. 310, no. 1-2, pp. 43-48, 2008.

[37] W. J. Trickler, W. G. Mayhan, and D. W. Miller, "Brain microvessel endothelial cell responses to tumor necrosis factor-alpha involve a nuclear factor kappa B (NF- $\kappa \mathrm{B})$ signal transduction pathway," Brain Research, vol. 1048, no. 1-2, pp. 24-31, 2005.

[38] N. K. Phulwani, N. Esen, M. Md. Syed, and T. Kielian, "TLR2 expression in astrocytes is induced by TNF- $\alpha$ - and NF- $\kappa \mathrm{B}$ dependent pathways," Journal of Immunology, vol. 181, no. 6, pp. 3841-3849, 2008.

[39] T. Y. Ma, G. K. Iwamoto, N. T. Hoa, et al., "TNF- $\alpha$-induced increase in intestinal epithelial tight junction permeability requires NF- $\kappa \mathrm{B}$ activation," American Journal of Physiology, vol. 286, no. 3, pp. G367-G376, 2004.

[40] C. Chiao, A. M. Carothers, D. Grunberger, G. Solomon, G. A. Preston, and J. C. Barrett, "Apoptosis and altered redox state induced by caffeic acid phenethyl ester (CAPE) in transformed rat fibroblast cells," Cancer Research, vol. 55, no. 16, pp. 35763583, 1995.

[41] A. Lin, "Activation of the JNK signaling pathway: breaking the brake on apoptosis," BioEssays, vol. 25, no. 1, pp. 17-24, 2003.
[42] A. Wullaert, K. Heyninck, and R. Beyaert, "Mechanisms of crosstalk between TNF-induced NF- $\kappa \mathrm{B}$ and JNK activation in hepatocytes," Biochemical Pharmacology, vol. 72, no. 9, pp. 1090-1101, 2006. 

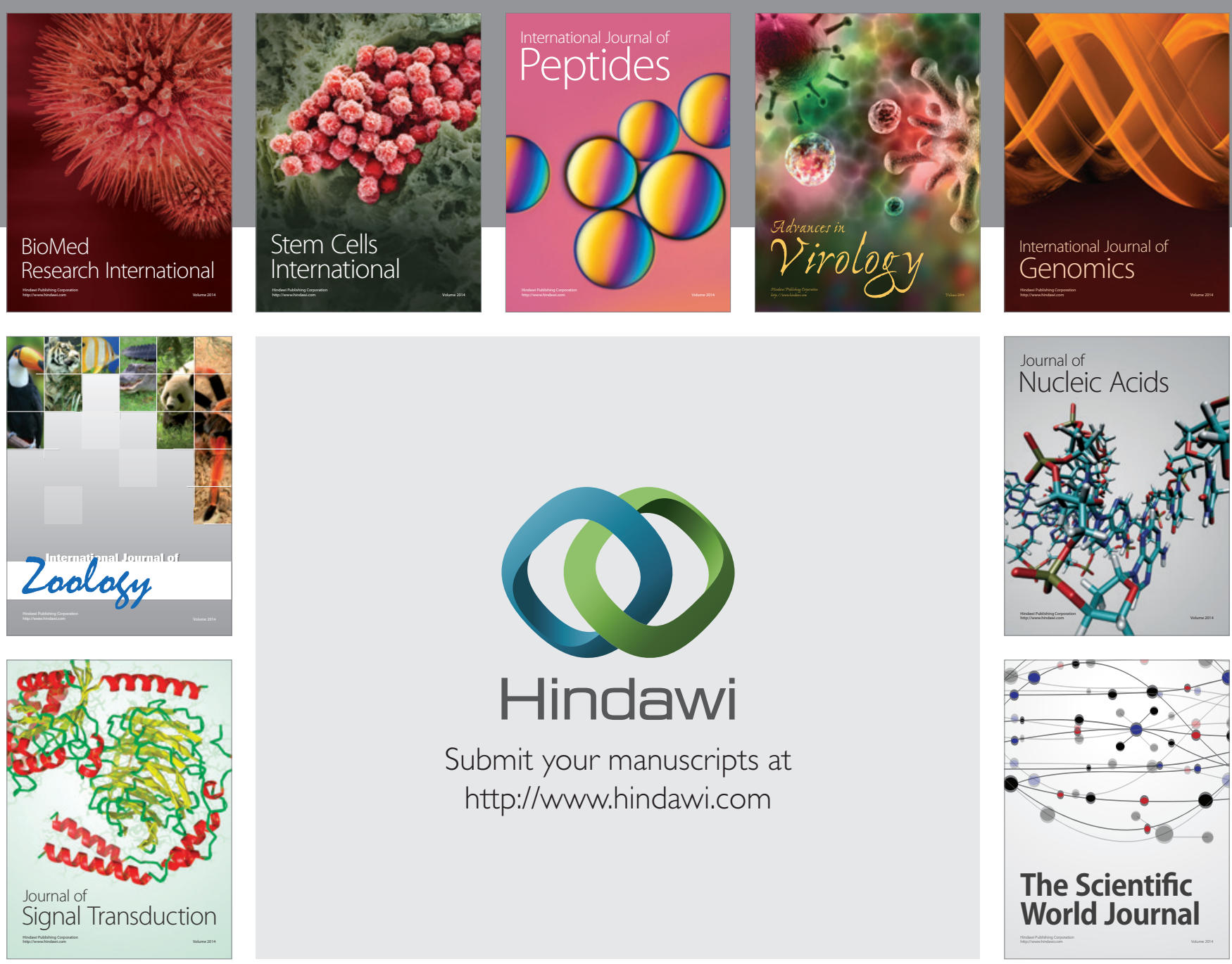

Submit your manuscripts at

http://www.hindawi.com
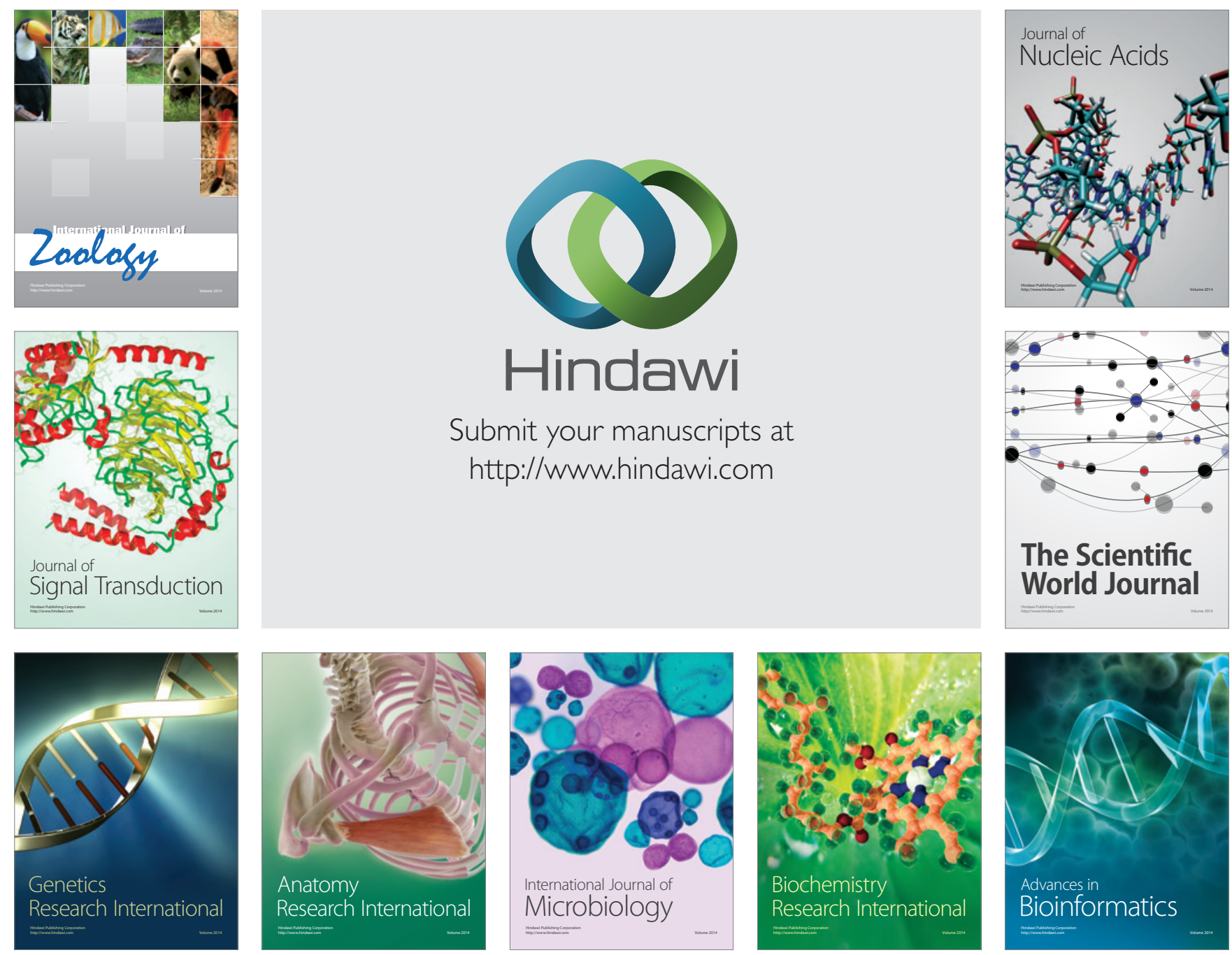

The Scientific World Journal
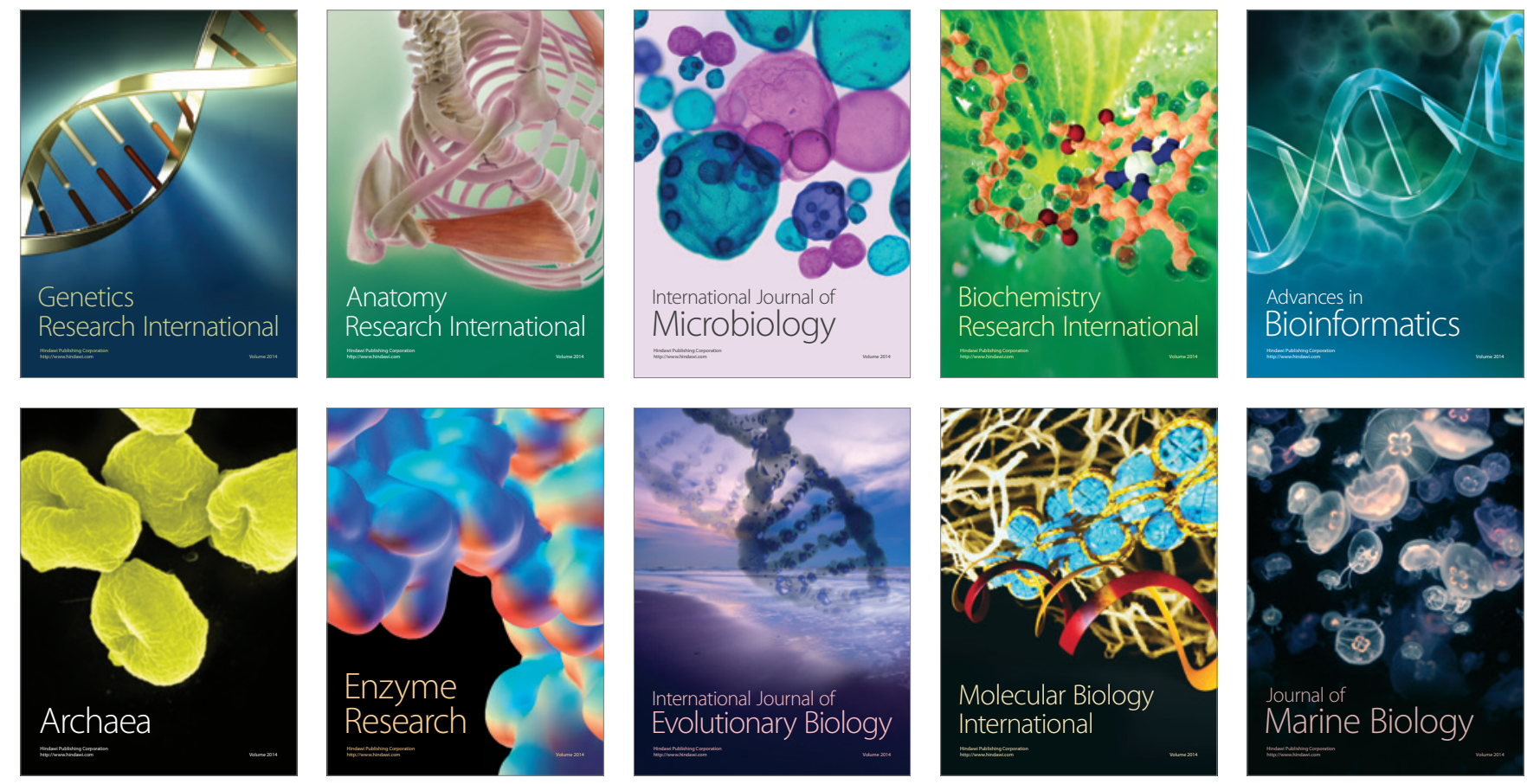